\title{
Soil Characterization and Land Suitability Evaluation to Cereal Crops in Yigossa Watershed, Northwestern Ethiopia
}

\author{
Yihenew G. Selassie ${ }^{1}$, Gizachew Ayalew ${ }^{2}$, Eyasu Elias $^{3} \&$ Mekonnen Getahun ${ }^{2}$ \\ ${ }^{1}$ College of Agriculture and Environmental Sciences, Bahir Dar University, Bahir Dar, Ethiopia \\ ${ }^{2}$ Amhara Design and Supervision Works Enterprise, Bahir Dar, Ethiopia \\ ${ }^{3}$ Capacity Building for Scaling up of Evidence-Based Best Practices in Agricultural Production in Ethiopia \\ (CASCAPE) project, Addis Ababa, Ethiopia
}

Correspondence: Yihenew G. Selassie, College of Agriculture and Environmental Sciences, Bahir Dar University, Bahir Dar, Ethiopia. E-mail: yihenewgs@gmail.com

Received: February 8, $2014 \quad$ Accepted: March 5, $2014 \quad$ Online Published: April 28, 2014
$\begin{aligned} & \text { doi:10.5539/jas.v6n5p199 } \\ & \text { URL: http://dx.doi.org/10.5539/jas.v6n5p199 }\end{aligned}$

\begin{abstract}
A study was conducted in 2013 at Yigossa watershed, Northwestern Ethiopia to characterize the soils using FAO criteria and evaluate their suitability to cereal crop producton. Surface soil samples from different soil types were collected and analyzed in the soil laboratory of Amhara Design and Supervision Works Enterprise. The collected soils were analyzed for soil $\mathrm{pH}$, organic matter, total $\mathrm{N}$ and available P. FAO guideline was used to evaluate the land suitability for selected cereal crops and geographical information system (GIS) was employed to analyze and map the soils within the watershed. Results indicated that the soils of the watershed were dominantly slightly acidic to slightly alkaline with $\mathrm{pH}$ ranging from 5.60 to 7.87 . The organic matter content ranged from $1.88 \%$ in Nitisols to $3.56 \%$ in Gleysols and Regosols; while the total $\mathrm{N}$ content ranged from $0.09 \%$ in Nitisols to $0.18 \%$ in Gleysols and Regosols. Available P contents varied from $1.78 \mathrm{mg} \mathrm{kg}^{-1}$ in Nitisols to $12.3 \mathrm{mg} \mathrm{kg}^{-1}$ in Regosols. Analysis of land suitability analysis showed that $60.9 \%$ of Nitisols, $38.2 \%$ of Gleysols, $36.1 \%$ of Luvisols and $23.4 \%$ of Regosols were moderately suitable for maize (Zea mays L.); while $32.5 \%$ of the Nitisols, $50.6 \%$ of Gleysols, $73.0 \%$ of Luvisols and $73.9 \%$ of Regosols were moderately suitable for finger millet (Eleusine coracana L.). Moreover, $51.4 \%$ of Nitisols, $38.2 \%$ of Gleysols, $68.7 \%$ of Luvisols and $60.2 \%$ of Regosols were moderately suitable for teff (Eragrostis tef Zucc.); whereas 32.5\% of Nitisols, $50.6 \%$ of Gleysols, $73.0 \%$ of Luvisols and $73.8 \%$ of Regosols were moderately suitable for rice (Oryza sativa L.). From the result of the study it was possible to conclude that different soils are variably suitable for different crops. In some cases, the same soil could be suitable for different crops bringing competing nature of crop land use types for the same parcel of land. However, yield per unit of land and return to investment dictates farmers' decision on land allocation for a particular use.
\end{abstract}

Keywords: soil analysis, land suitability evaluation, cereal crops, north-western Ethiopia, soil characterization, Yigossa watershed

\section{Introduction}

Ethiopia has a considerable land resource for agriculture. About 73.6 million ha $(66 \%)$ of the country's area is potentially suitable for agriculture (Fasil, 2002) and the Ethiopian agricultural sector has a proven potential to increase food supplies faster than the growth of the population (Davidson, 1992). Crop production plays a vital role in generating surplus capital to speed up the overall socio-economic conditions of the farmers. However, the country is unable to feed its people due to various bio-physical and socio-economic constraints and policy disincentives. Land degradation manifested in the form of soil erosion is one of the major bio-physical constraints.

Soil degradation is becoming a major policy challenge in Ethiopia not only for increasing crop productivity but also for maintaining soil resource base for the future generation. Accordingly, the potential of the land for crop production to sustainably satisfy the ever increasing food demand of the increasing population is declining as a result of severe soil degradation (Lal, 1994). The net soil loss from cultivated fields due to erosion ranged from 20 to $100 \mathrm{t} \mathrm{ha}^{-1}$ per year ${ }^{-1}$, with corresponding annual productivity loss of 0.1 to $2 \%$ of total production (Hurni, 
1993). G. Yihenew and B. Yihenew (2013) also reported that the value of nutrient replacement costs of available $\mathrm{N}$ (AN) and available phosphorus (AP) from non conserved croplands of Harfetay watershed, Northwestern Ethiopia to be 121.23 Birr ha ${ }^{-1}$ year ${ }^{-1}$ followed by conserved croplands (36.41 Birr ha $^{-1}$ year $^{-1}$ ) and grazing lands (32.22 Birr ha $^{-1}$ year $^{-1}$ ). The weighted mean replacement costs of AN and AP are 34.01 and 42.31 Birr ha $^{-1}$ year $^{-1}$, respectively $(1 \$=19$ Birr $)$.

To meet the increasing demand for food, farmers have to produce more. On the other hand, land is limited and successful agriculture requires the sustainable use of soils that significantly determine the agricultural potential of an area. Under present situation, where land is a limiting factor, it is impractical to bring more area under cultivation to satisfy the ever growing food demand (Fischer et al., 2002). Hence, it is essential to understand their nature and properties in order to preserve soils for future generations and for their most efficient use (FAO, 1998; Kanwar, 2004). The proper understanding of the nature and properties of the soils and their management based on their potentials and constraints is crucial for optimization of crop production to the potential levels (Abayneh \& Berhanu, 2006). However, soil characterization and assessment of land suitability for cereal crops were not yet done in Yigossa watershed. Hence, the main objective of the study was to spatially characterize the soils and evaluate their suitability for maize, finger millet, teff, and rice production.

\section{Materials and Methods}

\subsection{Description of the Study Watershed}

Soil samples were collected at Yigossa watershed located in Dera district, South Gonder Zone of Amhara National Regional State at about $597 \mathrm{~km}$ northwest of Addis Ababa. The watershed lies within 11 ${ }^{\circ} 46^{\prime} 24.5^{\prime \prime}$ $11^{\circ} 48^{\prime} 40.8^{\prime \prime}$ latitude and 37 $30^{\prime} 40.3^{\prime \prime}-37^{\circ} 34^{\prime} 15.6^{\prime \prime}$ longitude (Figure 1). The elevation ranges from 1802 to 1970 m.a.s.l. and the total area of the watershed is about 1092.68 ha dominated by $2-5 \%$ slope and covered by intensively cultivated crop fields.

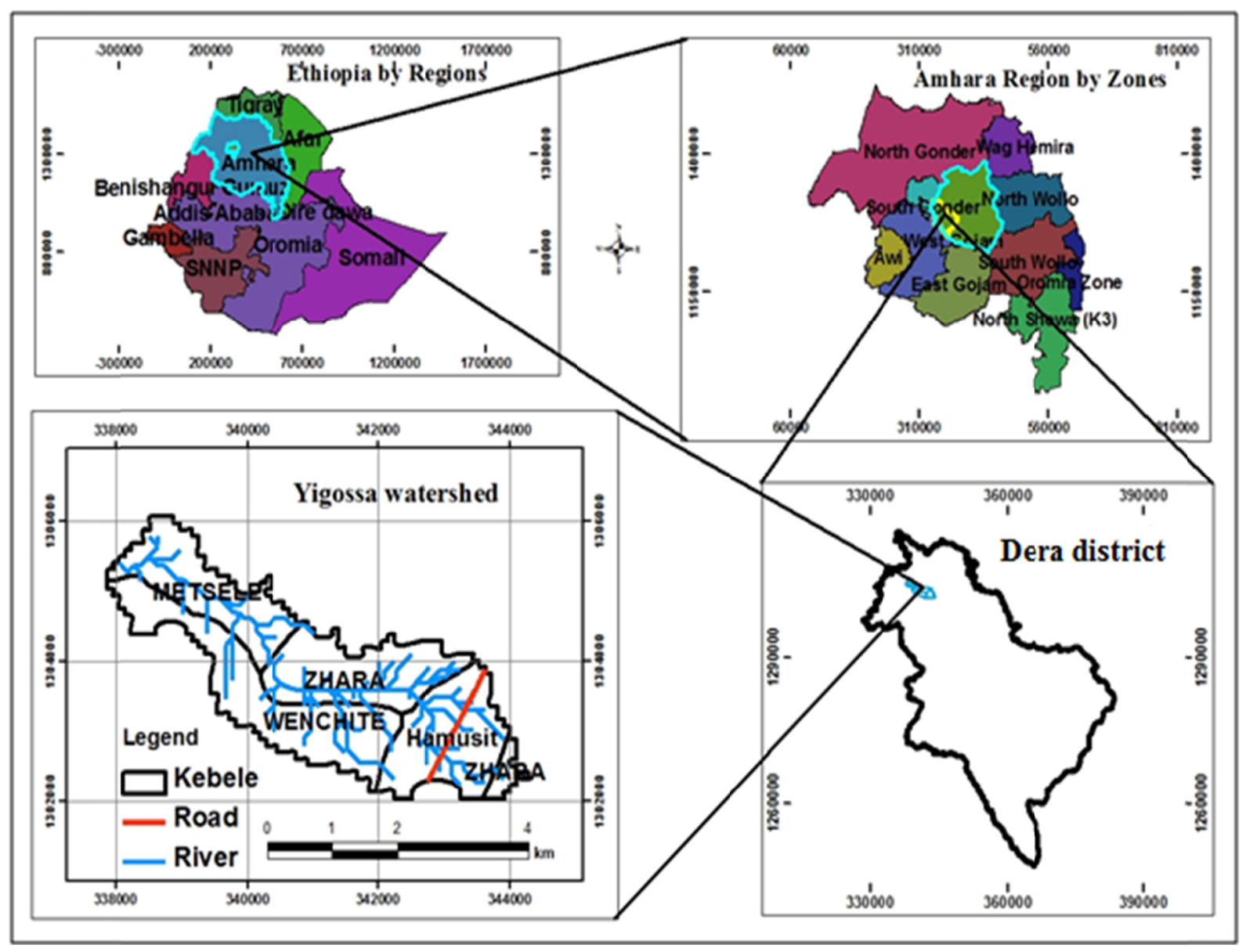

Figure 1. Location map of the study watershed 
Climatic data were collected by Bahir Dar station of the Ethiopian Meteorological Agency. The annual mean minimum and maximum temperatures of the study watershed are $17.5^{\circ} \mathrm{C}$ and $20^{\circ} \mathrm{C}$, respectively whereas the average annual rainfall ranges from 1200-1500 mm (DSA \& SCI, 2006). The climate of the study watershed is characterized as moist tepid.

The geological formation of the study watershed generally belongs to the basaltic Tapp Series of the Tertiary volcanic eruptions in general and Gunna mountain shield volcano in specific. The volcano corresponds to the eruptive events that occurred during the early Miocene to Pliocene period and classified in the shield group basalt (BCEOM, 1999; Kieffer et al., 2004). The common litho-type for this material is basalt with large amount of interbedded lava, volcanic ash and other acidic rocks such as rhyolite and trachyte.

\subsection{Methodology}

\subsubsection{Surface Soil Sampling, Analysis and Characterization}

Each major soil type was stratified into four soil sampling sites based on soil color and texture. From these sites, several auger observations were taken by Edelman auger at surface layer $(0-30 \mathrm{~cm})$ and bulked into 12 composite soil samples for surface soil characterization and crop suitability evaluation (Figure 2). The soil samples collected from surface layer were air dried at room temperature and ground to pass through $2 \mathrm{~mm}$ sieve for all the soil parameters except for total nitrogen (TN) and organic carbon (OC) which passed through $0.5 \mathrm{~mm}$ sieve. Soil pH was measured potentiometrically using a digital $\mathrm{pH}$ meter in the supernatant suspension of $1: 2.5$ (soil: water). The OC content was analyzed following the Walkley and Black wet digestion method (Nelson \& Sommers, 1982). The Kjeldahl procedure was followed for the determination of TN (Bremner \& Mulvaney, 1982). Available phosphorus (AP) was determined by Bray II method as described by Bray and Kurtz (1945) and measured with spectrophotometer (Murphy \& Riley, 1962). Soil characterization was then carried out based on the data obtained from soil laboratory analysis result.

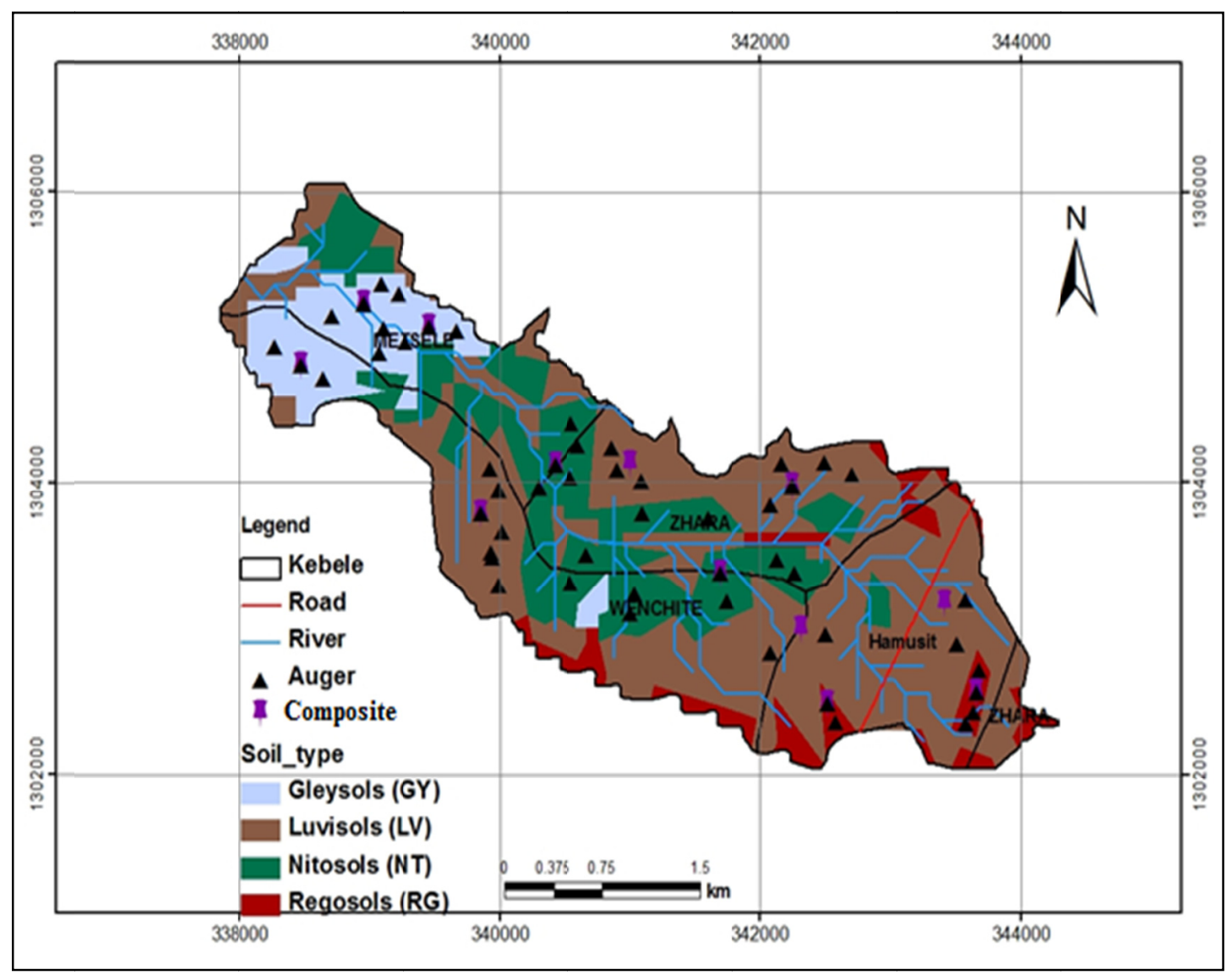

Figure 2. Auger observations and composite sampling sites 


\subsubsection{Land Suitability Classification}

Land suitabilities for maize (Zea mays L.), finger millet (Eleusine coracana L.), teff (Eragrostis tef Zucc.) and rice (Oryza sativa L.) were evaluated using FAO (1976) guidelines. The crop land utilization types (LUTs) were selected through discussion with the key informant farmers and development agents. When crop selection was carried out, area coverage, importance of the crops in the livelihood of the concerned community, suitability of soils and agro-climatic conditions of the study watershed were evaluated (FAO, 1998).

The evaluation criteria used to address the suitability of the selected crop LUTs in the study watershed were soil chemical characteristics ( $\mathrm{pH}, \mathrm{OC}, \mathrm{TN}$ and $\mathrm{AP}$ ), slope and climatic factors (temperature and length of growing period [LGP]). In this study, the factors were selected based on agronomic knowledge of local experts and reviews of existing literatures such as FAO framework for land evaluation (FAO, 1998).

Digital data of land characteristics (LCs) of major soil types and classifier look up tables for crop land use requirements (LURs) were properly encoded to the Microsoft Office Excel sheet as database file to be used in Arc GIS for spatial analysis. Point data of the selected LCs generated from composite samples were spatially interpolated using Kriging tool in Arc GIS. In addition, the LCs were reclassified based on crop LURs. Crop land suitability evaluation at present condition was then made in an area of about 1092.68 ha by matching between reclassified LCs of major soil types with crop LURs using GIS model builder (Figure 3). The model builder uses maximum limitation method so that the most limiting climatic or soil parameter dictates the final level of suitability (Sys et al., 1991; Van Diepen et al., 1999).

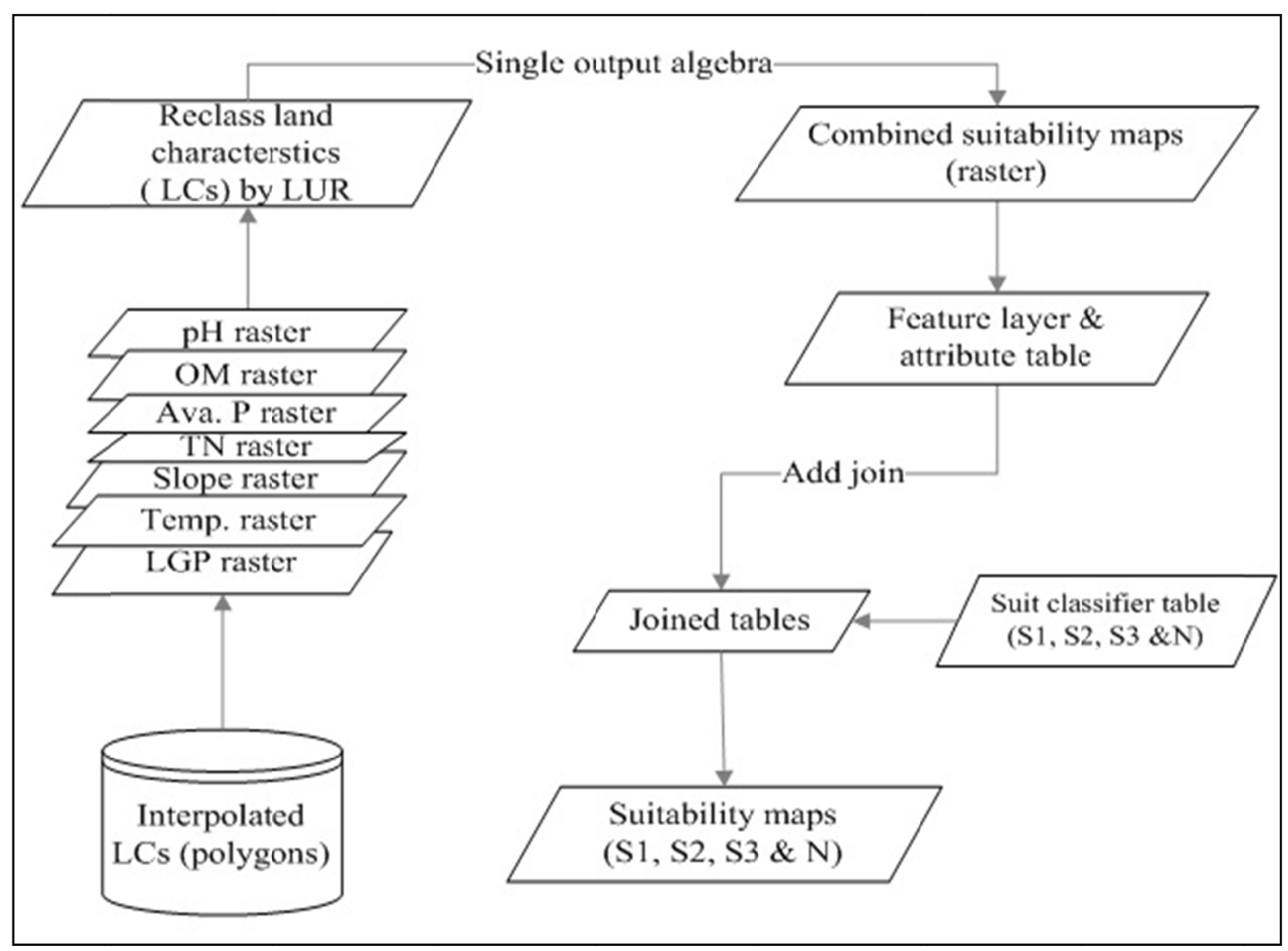

Figure 3. Procedures followed and outputs produced by model builder in Arc GIS

\section{Results and Discussion}

\subsection{Soil Characterization}

The chemical characteristics of the soils of Yigossa watershed are presented in Table 1. The $\mathrm{pH}$ values varied from 5.6 to 7.87. Nitisols were neutral, Luvisols slightly acidic, Regosols moderately acidic, and Gleysols slightly alkaline. Belay (1996) reported that Luvisols located in the steep slopes are slightly alkaline. Moreover, 
acidic nature of Nitisols was reported by several authors (Yihenew, 2002; Getachew \& Heluf, 2007; Abebe \& Endalkachew, 2012). Slightly alkaline nature of Gleysols at soil surface could be attributed to the influx of the exchangeable bases particularly $\mathrm{Ca}^{2+}$ and $\mathrm{Mg}^{2+}$ by alluvial-colluvial depositions from adjacent upper slopes and less mineralization rate of organic matter. Moderate acidity of Nitisols in the study watershed could be caused by one or a combination of factors such as crop removal, continuous cultivation practices, leaching of basic cations, continuous use of only two acidifying fertilizers (urea and di-ammonium phosphate) coupled with the decomposition of organic residues (Landon, 1991; Ahmed, 2002). According to FAO (1998), moderately acidic soils may be deficient in phosphorus, calcium, magnesium and molybdenum.

The AP content was generally medium throughout the study watershed according to Landon (1991). This might be due to the influence of organic matter and added P containing fertilizers (Sharma et al., 2008). However, low AP in Gleysols might be due to severe leaching from the excessive moisture content observed in these soils. Nitisols in Ethiopia are reported to have low available P due to their inherently low P content, high P fixation by $\mathrm{Al}$ and $\mathrm{Fe}$ and complete removal of the biomass from the fields (Birru \& Heluf, 2003; Abebe \& Endalkachew, 2012). Studies made in Liberia also showed that acidic soils are generally deficient in AP (Getachew \& Sommer, 2000). This soils would most likely respond to judicious phosphorus containing fertilizer application (FAO, 1998).

The OM content of surface soils ranged from 1.88 to $3.56 \%$ and TN varied from 0.09 to $0.18 \%$. TN contents of soils generally ranged from less than $0.02 \%$ in sub-soils to greater than $2.5 \%$ in peat soils (Tisdale et al., 2002). Medium to high OM and TN contents at surface layer could be attributed to poor drainage condition of the soil that reduces the rate of organic matter decomposition; and the addition of farmyard manure and plant residues that are rich in carbon and nitrogen. Similarly, higher organic carbon and nitrogen in Nitisols and Luvisols were reported by Ahmed (2002); Yihenew (2002) and Getachew and Heluf (2007). Conversely, high organic matter and low nitrogen contents in Nitisols (Shimeles et al., 2006) and low TN in Luvisols (Belay, 1996) were reported in the highlands of Ethiopia.

Table 1. Soil types and their chemical characteristics in the study watershed

\begin{tabular}{lcccc}
\hline Soil type & $\begin{array}{c}\mathrm{pH}\left(\mathrm{H}_{2} \mathrm{O}\right) \\
(1: 2.5)\end{array}$ & $\begin{array}{c}\mathrm{OM} \\
(\%)\end{array}$ & $\begin{array}{c}\mathrm{TN} \\
(\%)\end{array}$ & $\begin{array}{c}\mathrm{AP} \\
\left(\mathrm{mg} \mathrm{kg}^{-1}\right)\end{array}$ \\
\hline Nitisols & $5.6-7.87$ & $1.88-3.23$ & $0.09-0.16$ & $1.78-13.4$ \\
Luvisols & $6.23-6.34$ & $3.16-3.43$ & $0.16-0.17$ & $10.8-14.9$ \\
Gleysols & $5.99-6.17$ & $3.03-3.56$ & $0.15-0.18$ & $8.19-9.78$ \\
Regosols & $5.62-6.14$ & $2.49-3.56$ & $0.12-0.18$ & $10.6-12.3$ \\
\hline
\end{tabular}

\subsection{Land Suitability Evaluation}

The results of land suitability assessment showed that the four soil types available in the watershed varied in suitability for cereal crops. They were moderately suitable (S2), marginally suitable (S3), and currently not suitable $(\mathrm{N})$ depending on the site prospected. Because of one or more limitation(s) of the land characteristics, none of the area in the study watershed fallen in to highly suitable (S1) class for the selected crops. As shown in Table 2 , from the total area covered by Nitisols, $60.93 \%$ was moderately suitable for maize, $32.49 \%$ for finger millet, $51.39 \%$ for teff and $32.49 \%$ for rice cultivation. This is in line with the report of Henok (2010) and Kassa and Mulu (2012) in the Tigray Region. Woubet et al. (2013) also found that 40\% of similar soils of Anjeni watershed were moderately suitable for maize and teff. A study in India on similar soils also showed that $50.28 \%$ of area was marginally suitable for maize cropping while $24.34 \%$ was highly suitable and $6.34 \%$ was moderately suitable (Mustafa et al., 2011). The major suitability limitations reported for these soils were low organic matter and nitrogen contents and acidic $\mathrm{pH}$. Another study in Iran also indicated that soils with high $\mathrm{pH}$, low organic matter, high salinity and alkalinity were non-suitable for maize production (Ali et al., 2008).

The current study also indicated that $36.13 \%$ of Livisols were moderately suitable for maize, $72.95 \%$ form finger millet, $68.73 \%$ for teff and $72.95 \%$ for rice production. The major limitation for teff cultivation was low available $\mathrm{P}$ and short length of growing period (LGP). This result partially disagrees with the conclusion of Rabia (2012) in the Kilte Awulaelo district (Tigray Region) where 3.6\% of these soils were highly suitable for teff and slope had the major impact on its suitability. A study in India also showed that finger millet was extensively cultivated in nutrient poor soils (Mustafa et al., 2011). High pH was, however, the major limitation 
which excluded about $14.78 \%$ of the area from cultivation of finger millet. Similarly, 38.22, 50.59, 38.22 and $50.59 \%$ of Gleysols were moderately suitable for maize, finger millet, teff and rice, respectively. Low available $\mathrm{P}$ in all soils and $\mathrm{pH}$ in Gleysols were the major amendable limitations. Similar study indicated that rice was highly suitable in wetland soils of Nigeria (Olaleye et al., 2002). However, the major limitations to rice cultivation could be low organic carbon and available P contents. Moreover, 23.38, 73.81, 60.23 and 73.81\% of Regosols were moderately suitable for maize, finger millet, teff and rice, respectively. However, large area of the land $(44.59 \%)$ in these soils was found to be currently unsuitable for maize production. As per the observation made in the watershed, the main reason could be shallow soil depth and low water holding capacity of the soil.

Table 2. Suitability evaluation of Nitisols, Luvisols, Gleysols and Regosols for differet crops

\begin{tabular}{|c|c|c|c|c|c|c|c|c|c|}
\hline \multirow{3}{*}{ Soil type } & \multirow{3}{*}{ Suitability Class } & \multicolumn{2}{|c|}{ Maize } & \multicolumn{2}{|c|}{ Finger millet } & \multicolumn{2}{|c|}{ Teff } & \multicolumn{2}{|c|}{ Rice } \\
\hline & & \multicolumn{8}{|c|}{ Area } \\
\hline & & ha & $\%$ & ha & $\%$ & ha & $\%$ & ha & $\%$ \\
\hline \multirow[t]{3}{*}{ Nitisols } & Moderately suitable & 156.55 & 60.93 & 83.49 & 32.49 & 132.05 & 51.39 & 83.49 & 32.49 \\
\hline & Marginally suitable & 93.76 & 36.49 & 157.92 & 61.46 & 47.78 & 18.60 & 157.92 & 61.46 \\
\hline & Currently not suitable & 6.63 & 2.58 & 15.53 & 6.04 & 77.11 & 30.01 & 15.53 & 6.04 \\
\hline \multirow[t]{3}{*}{ Luvisols } & Moderately suitable & 227.92 & 36.13 & 460.22 & 72.95 & 433.57 & 68.73 & 460.22 & 72.95 \\
\hline & Marginally suitable & 191.55 & 30.36 & 163.04 & 25.84 & 197.29 & 31.27 & 163.04 & 25.84 \\
\hline & Currently not suitable & 211.39 & 33.51 & 7.60 & 1.20 & 0.00 & 0.00 & 7.60 & 1.20 \\
\hline \multirow[t]{3}{*}{ Gleysols } & Moderately suitable & 47.98 & 38.22 & 63.51 & 50.59 & 47.98 & 38.22 & 63.51 & 50.59 \\
\hline & Marginally suitable & 68.22 & 54.34 & 22.98 & 18.30 & 68.22 & 54.34 & 22.98 & 18.30 \\
\hline & Currently not suitable & 9.35 & 7.45 & 39.06 & 31.11 & 9.35 & 7.45 & 39.06 & 31.11 \\
\hline \multirow[t]{3}{*}{ Regosols } & Moderately suitable & 18.55 & 23.38 & 58.55 & 73.81 & 47.78 & 60.23 & 58.55 & 73.81 \\
\hline & Marginally suitable & 25.41 & 32.03 & 20.78 & 26.19 & 31.55 & 39.77 & 20.78 & 26.19 \\
\hline & Currently not suitable & 35.37 & 44.59 & 0.00 & 0.00 & 0.00 & 0.00 & 0.00 & 0.00 \\
\hline
\end{tabular}

It was found that $30.98 \%$ of the study area was moderately and $57.55 \%$ marginally suitable for all crops (Table 3). In fact, Nitisols and Regosols were moderately suitable for all crop production, while Luvisols were marginally suitable. Gleysols were moderately suitable for maize, finger millet, teff and rice production. This indicates competing nature of crop land use types for the same land. Available $\mathrm{P}$ for all soils and $\mathrm{pH}$ for Nitisols, Luvisols and Gleysols were found to be limiting factors that should be optimized for sustainable and increased crop production and for effective use of the soils of the study watershed.

Table 3. Land suitability for major cereal crops

\begin{tabular}{lcc}
\hline Suitability classes & \multicolumn{2}{c}{ Area } \\
\cline { 2 - 3 } & ha & $\%$ \\
\hline S2 for maize, finger millet, teff and rice & 338.49 & 30.98 \\
S3 for maize; S2 for finger millet, teff and rice & 125.39 & 11.48 \\
S3 for maize, finger millet, teff and rice & 628.8 & 57.55 \\
\hline
\end{tabular}

$\mathrm{S}_{2}=$ moderately suitable; $\mathrm{S}_{3}=$ marginally suitable.

\section{Conclusions}

The study has produced map on the suitability of the different soil types of Yigossa watershed that will allow growing the right cereal crop at the right site for optimum yield and optimum return to investment for each of maize, finger millet, teff and rice. Proper agricultural practices such as liming and addition of organic matter would contribute to improving the availability of phosphorus and modifying soil $\mathrm{pH}$. 


\section{Acknowledgements}

This study was part of the Capacity Building for Scaling up of Evidence-Based Best Practices in Agricultural Production in Ethiopia (CASCAPE) project on increasing agricultural productivity in Ethiopia. The CASCAPE project is funded by the Dutch Ministry of Foreign Affairs through the Embassy of the Kingdom of The Netherlands in Addis Ababa, Ethiopia. The Amhara Design and Supervision Works Enterprise (ADSWE) is also acknowledged for permitting the analysis of the soil samples in its laboratory.

\section{References}

Abayneh, E., \& Berhanu, D. (2006). Soil survey in Ethiopia: The past, present and future. Proceeding of the 7th Conference of the Ethiopian Society of Soil Science on Soils for Sustainable Development (pp. 61-79). Addis Ababa, Ethiopia.

Abebe, N., \& Endalkachew, K. (2012). Physicochemical characterization of Nitisol in Southwestern Ethiopia and its fertilizer recommendation using NuMaSS. Global Advanced Research Journal of Agricultural Science, 1(4), 066-073.

Ahmed, H. (2002). Assessment of Spatial Variability of Some Physicochemical Characteristics of Soils under Different Elevations and Land Use Systems in the Slopes of Mount Chilalo. M.Sc. Thesis, Alemaya University, Ethiopia.

Ali, A., Jafar, Z., Parisa, A. I., Mohamed, R. N., \& Siamak, S. (2008). Land suitability evaluation of Bilverdy research station for wheat, barley, alfalfa, maize and safflower. Soil and Water Research, 3, S81- S88.

BCEOM-French Engineering Consultants. (1999). Abbay River Basin Integrated Development Master Plan Project Phase 2 Report. Addis Ababa. Ethiopia.

Belay, T. (1996). Characteristics and landscape relationships of Vertisols and vertic Luvisols of Melbe Tigray in Ethiopia. SINET: Ethiopian Journal of Science, 19(1), 93-115.

Birru, Y., \& Heluf, G. (2003). Kinetics of phosphorus for some selected soils of the north-western highlands of Ethiopia. In T. Amede \& E. Zewdie (Eds.), Challenges of land degradation to agriculture in Ethiopia. Proceeding of the $6^{\text {th }}$ ESSS conference.

Bray, R. H., \& Kurtz, L. T. (1945). Determination of total organic and available forms of phosphorus in soils. Soil Society, 59, 39-45.

Bremner, J. M., \& Mulvaney, C. S. (1982). Total Nitrogen. In A. L. Page, R. H. Miller, \& D. R. Keeney (Eds.), Methods of soil analysis. II. Chemical and microbiological properties (pp. 595-624). American Society of Agronomy, Soil Science Society of America.

Davidson, D. A. (1992). The Evaluation of Land Resources. Stirling University press, USA, NewYork.Development Studies Associates (DSA) \& Shawel Consult International (SCI). (2006). Potential Survey, Identification of Opportunities and Preparations of Projects Profiles and Feasibility Studies. Addis Ababa, Ethiopia.

FAO. (1976). Framework for Land Evaluation (pp. 17-21). FAO Soil Bulletin No.32, FAO, Rome.

FAO. (1984). Crop Environmental Requirements Report prepared for the Government of Ethiopia. Technical Report 5 Part III, FAO, Rome, Italy.

FAO. (1998). Guidelines on Land Evaluation for Rainfed Agriculture. Soils Bulletin No.52, FAO, Rome, Italy.

Fasil, K. (2002). Analysis of Yield Gap for Wheat Cultivation in the Highlands of North Ethiopia. Ph.D. Thesis, Gent University, Belgium.

Fischer, G., Velthuizen, H. V., Shah, M., \& Nachtergaele, F. (2002). Global Agro-ecological Assessment for Agriculture in the $21^{\text {st }}$ Century: Methodology and Results. International Institute for Applied Laxenburg in Australia.

Getachew, A., \& Sommer, K. (2000). Optimisation of the efficiency of phosphate fertilizers in acidic-ferralitic soils of the humid tropics. Ethiopian Journal Natural Resource, 2(1), 63-77.

Getachew, F., \& Heluf, G. (2007). Characterization and fertility status of the soils of Ayehu research substation in Northern highlands of Ethiopia. East African Journal of Sciences, 1(2), 160-169.

Henok, M. (2010). Land Suitability and Crop Suitability Analysis Using Remote Sensing and GIS Application of Legambo district in Ethiopia. 
Hurni, H., \& Pimentel, D. (1993). Land degradation, famine, and land resource scenarios in Ethiopia. World soil erosion and conservation (pp. 27-61).

Kanwar, J. S. (2004). Address by the guest of honour. 69th Annual Convention of the Indian Society of Soil Science held at the Acharaya. Hyderabad, India.

Kieffer, B., Arndt, N., Lapierre, H., Bastien, F., Bosch, D., Pecher, A., ... Meugniot, C. (2004). Flood and shield from Ethiopia: Magmas from the African supper swell. Journal of Petrology, 45, 793-834.

Lal, R. (1994). Sustainable land use systems and soil resilience. In D. J. Greenland \& I. Szabolcs (Eds.), Soil Resilience and Sustainable Land Use, pp. 41-67. UK: CAB International.

Landon, J. R. (1991). Booker Tropical Soil Manual, a hand book for Soil Survey and Agricultural Land Evaluation in the Tropics and Subtropics. Longman.

Murphy \& Riley (1962). Principles of Soil Mechanics and Foundation Engineering. UBS Publisher Ltd.

Mustafa, A. A., Man, S., Sahoo, R. N., Nayan, A., Manoj, K., Sarangi, A., \& Mishra, A. K. (2011). Land suitability analysis for different crops. A multi criteria decision making approach using remote sensing and GIS. Indian Agricultural Research Institute, 3(12), 1-24.

Nelson, D. W., \& Sommers, L. E. (1982). Total carbon, organic carbon and organic matter. In A. L. Page (Ed.), Methods of Soil Analysis. Part 2: Chemical and Microbiological properties (pp. 539-579). Agronomy 9. Madison, Wisconsin.

Olaleye, A. O., Ogunkunle, A. O., Sahrawat, K. L., Osiname, O. A., \& Ayanlaja, S. A. (2002). Suitability evaluation of selected wetland soils in Nigeria for rainfed rice cultivation. Tropicultura, 20(3), 97-103.

Rabia, A. H. (2012). GIS spatial modeling for land degradation assessment in Tigray, Ethiopia. 8th International Soil Science Congress on Land Degradation and Challenges in Sustainable Soil Management (pp. 161-167). Çeşme-Izmir, Turkey.

Sharma, P. K., Sood, A., Setia, R. K., Tur, N. S., Mehra, D., \& Singh, H. (2008). Mapping of micronutrients in soils of Amritsar District at Punjab. Journal of Indian Society Soil Science, 56, 34-41.

Shimeles, D., Mohammed, A., \& Abayneh, E. (2006). Characterization and Classification of the Soils of Tenocha-Wenchancher Microcatchment in Southwest Shewa. M.Sc. Thesis, Alemaya University.

Sys, I., Van Ranst E., \& Debaveye J. (1991). Part II Methods in Land Evaluation. Agriculture Publication No.7, General Administration for Development Cooperation (pp. 70-76). Brussels, Belgium.

Teka, K., \& Haftu, M. (2012). Land Suitability Characterization for Crop and Fruit Production in Midlands of Tigray, Ethiopia. Momona Ethiopian Journal of Science, 4(1), 64-76.

Tisdale, S. L., Nelson, W. L., Beaton, J. D., \& Havlin, J. L. (2002). Soil Fertility and Fertilizer (7th ed.). Prentice-Hall of India, Newdelhi.

Van Diepen, C. A., Van Keulen, H., Wolf, J., \& Berkhout, J. A. A. (1999). Land Evaluation: From Intuition to Quantification. In B. A. Stewart (Ed.), Advances in Soil Science (pp. 139-204). New York: Springer.

Woubet, A., Tadele, A., Birru, Y., Yihenew, G., Bettina, W., \& Hans, H. (2013). Impacts of soil and water conservation on land suitability to crops in Anjeni watershed of Northwest Ethiopia. Journal of Agricultural Science (1916-9752), 5(2), 95-109. http://dx.doi.org/10.5539/jas.v5n2p95

Yihenew, G. (2002). Selected chemical and physical characteristics of soils of Adet research centre and its testing sites in Northwestern Ethiopia. Ethiopian Journal of Natural Resource, 4(2), 199-215.

Yihenew G., \& Yihenew, B. (2013). Costs of Nutrient Losses in Priceless Soils Eroded from the Highlands of Northwestern Ethiopia. Journal of Agricultural Science (1916-9752), 5(7), 206-214. http://dx.doi.org/10.5539/jas.v5n7p227

\section{Copyrights}

Copyright for this article is retained by the author(s), with first publication rights granted to the journal.

This is an open-access article distributed under the terms and conditions of the Creative Commons Attribution license (http://creativecommons.org/licenses/by/3.0/). 